\title{
A survey of a footwear service for people with Rheumatoid Arthritis (RA)
}

\author{
Robert Field \\ From Society of Chiropodists and Podiatrists Annual Conference 2010 \\ Bournemouth, UK. 21-23 October 2010
}

\section{Background}

Despite the DLF report 'Footwear - a quality issue' (1991), examples of poor usage of provided NHS footwear continue to be reported [1]. For footwear to be worn, design and fit to meet clinical needs plus the patient's non clinical criteria have to be addressed [2]. Locally a specialist footwear service provides semibespoke and stock footwear to people with RA related foot pathology. Patients are fully included within decisions concerning provision. Service delivery is jointly by Shoefitter and Podiatrist.

\section{Method}

A postal questionnaire was sent to 34 patients receiving footwear in 2009-10. Data from the 27 replies relating to the overall footwear service, quality and choice aspects to the provision, its usage and impact of provision is reported.

\section{Results}

All were 'very satisfied / satisfied' with the clinic. Mean score of footwear characteristics (fitting; comfort; leather, colour, fastening and style choice) was 86.12/ 100. Mean footwear comfort was 8.65/10. 20 reported using footwear most/everyday. Since provision, 5 reported reduced podiatry need, 19 indicated changes in foot problems and 18 indicated improved activity participation.

\section{Conclusions}

Results indicate high level of satisfactions with the footwear service and suggest a positive impact on individual's participation in activities.

Published: 20 December 2010

Bournemouth and Poole Community Health Services, Bournemouth, UK
References

1. Otter SJ, et al: Foot pain in rheumatoid arthritis prevalence, risk factors and management: an epidemiological study. Clin Rheumatol 2010, 29:255-271.

2. Williams $A E$, Nester $C J$ : Shoes in the cupboard: the fate of prescribed footwear? Prosthetics and Orthotics International 2006, , 25: 53-59.

doi:10.1186/1757-1146-3-S1-P9

Cite this article as: Field: A survey of a footwear service for people with Rheumatoid Arthritis (RA). Journal of Foot and Ankle Research 2010 3(Suppl 1):P9.
Submit your next manuscript to BioMed Central and take full advantage of:

- Convenient online submission

- Thorough peer review

- No space constraints or color figure charges

- Immediate publication on acceptance

- Inclusion in PubMed, CAS, Scopus and Google Scholar

- Research which is freely available for redistribution
() Biomed Central

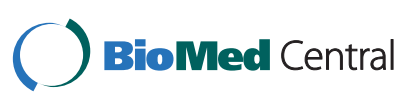

